\title{
GLOBAL CHANGES IN RESIDENTIAL ENERGY CONSUMPTION
}

María del P. Pablo-Romero ${ }^{\mathrm{a}}$, Rafael Pozo-Barajas ${ }^{\mathrm{b}}$, and Rocío Yñiguez ${ }^{\mathrm{c}}$

\section{a. Corresponding author}

Department of Economic Analysis and Political Economy

Faculty of Economics and Business Sciences, University of Seville Ramon y Cajal 1, 41018 Seville, Spain

Associate Researcher, Universidad Autónoma de Chile, Chile

Tel.: +34 954557 611. Fax: +34954557629

mpablorom@us.es

b. Department of Financial Economy and Operations Management

Faculty of Economics and Business Sciences, University of Seville

Ramon y Cajal 1, 41018 Seville, Spain

Tel.: +34 954556 463. Fax: +34 954557570

pozo@us.es

c. Department of Economic Analysis and Political Economy

Faculty of Economics and Business Sciences, University of Seville

Ramon y Cajal 1, 41018 Seville, Spain

Tel.: +34 954557 529. Fax: +34 954554481

ovando@us.es 


\title{
GLOBAL CHANGES IN RESIDENTIAL ENERGY CONSUMPTION
}

\begin{abstract}
The residential energy sector is crucial to achieving $\mathrm{CO}_{2}$ emission reductions as it has an important energy-saving potential, and its environmental controls are difficult to displace to other countries. Using the latest available data, this short paper provides a concise analysis of residential energy consumption trends for the period 1993-2013 in a double perspective, by main world regions and by per capita gross national income levels in 2013. Residential energy has been divided into three types: non-renewable, direct renewable and indirect renewable. Annual rates of change, energy intensity, energy in per capita terms and some ratios have been analyzed. Notable regional differences and trends were observed in the studied variables. Therefore, different energy policies are recommended for the regions. Eastern and Southern Asian countries, the EU15 and other developed countries, are the regions which should make the greatest effort to reduce residential energy consumption. The promotion of direct and indirect renewable energies is recommended.
\end{abstract}

Keywords: Climate and energy policy; residential energy; worldwide regional analysis. JEL code: Q2, Q48, Q58, R1, R58 


\section{GLOBAL CHANGES IN RESIDENTIAL ENERGY CONSUMPTION}

\section{Introduction}

Growing world energy consumption is putting increasing pressure on environmental pollution and global warming. Recently, the Paris Climate Conference (COP21) agreement set out an action plan to avoid climate change by keeping the increase in global average temperature to well below $2^{\circ} \mathrm{C}$ (Burleson, 2016). In order to achieve this target, energy consumption and Green House Gas (GHG) emissions must be reduced in all economic sectors.

The residential energy (RE) sector has become key to undertaking rapid emission reductions in a two-fold sense. Firstly, because the residential sector represents around $25 \%$ of global energy consumption, and $17 \%$ of global $\mathrm{CO}_{2}$ emissions (IEA, 2016), and therefore has direct significant effects on the world environment (Nejat et al., 2015). Thus, this energy sector has a vital role in mitigating these emissions, because, as stated in IEA (2011), its global energy-saving potential is around $0.48 * 10^{6}$ Ktoe per year. Secondly, because the residential emissions productions are difficult to displace to other countries, the applied energy policies are therefore more globally-effective in this sector. In that context, some authors, such as Kanemoto et al. (2014), point out that many countries are reducing their emissions, and even fulfilling their Kyoto Protocol commitments. Nevertheless, they may have achieved these commitments partially because they have displaced polluting industries to other countries, where environmental standards are quite low (Lau et al., 2014). Residential environmental controls are difficult to displace to other countries and therefore energy policies may be more efficient than in other sectors.

Despite the importance of the residential energy sector, there are few studies focusing on its heterogeneity across the world. Some studies refer to a specific part of 
the world, such as, for example, the EU (Filippini et al., 2014a, 2014b), the USA (Lee and Lee, 2012), China (Zhao et al., 2012) or Lithuania (Štreimikienè, 2014). From a more general perspective, Nejat et al. (2015) review the status and trends of energy consumption in the residential sector globally, and in ten countries. However, very little attention has been given to certain regions, such as Africa, Latin America and the Middle East and to economies in transition. This is despite the fact that, as stated in Mundaca et al. (2013), the causes and/or impacts of climate change are mostly framed in regional terms. Therefore, much more research on geographical differences is needed (Bridge et al., 2013).

On the other hand, most studies referring to residential energy and income are focused on the role of the economic behavior of resident households using micro data. Along this line, for example, the recent study by Gertler et al. (2016) analyses the household decisions to acquire energy-using assets in the presence of rising incomes. The findings of this study are consistent with previous work describing an S-shaped relationship between household income and appliance acquisitions, as for example Jamasb and Meier (2010) and Wolfram et al. (2012). These findings suggest that residential energy demand growth may be different, depending on the households' income level. From a macroeconomic perspective, there are much fewer studies. Among them, the study by Auffhammer and Wolfram (2014) presents evidence suggesting that the shape of the income distribution plays a major role in driving household acquisition of energy-using goods in China. These results are consistent with previous work documenting the S-shaped relationship. In that sense, the authors state that there is going to be a large increase in the demand for residential energy in the coming years, as the income grows. Therefore, more research on the relationships between residential 
energy consumption and income; to link these findings to macro-level trends in energy consumption is needed in order to be able to apply effective energy policies.

The aim of this short paper is to provide a concise analysis of residential energy consumption trends for the period 1993-2013 in a two-fold perspective, by 11 main world regions, and by per capita gross national income (GNI) levels in 2013, covering 4 groups. The results of the paper may be taken as a starting point for additional and deeper analyses regarding regional economies.

\section{Methodology}

Residential energy (RE) consumption world data are analyzed and presented by world regions and by GNI levels. The RE has been divided into three types of energy: non-renewable residential energy (NRRE), direct renewable residential energy (DRRE) and indirect renewable residential energy (IRRE). Additionally, total renewable residential energy consumption (TRRE) has been calculated by adding DRRE and IRRE. Annual changes, energy intensity (ratio of energy consumption to GDP in Purchasing Power Parity - PPP) and energy in per capita terms have been analyzed for these variables. Additionally, the trend of the following ratios has been studied: RE to total energy (TE) consumption, DRRE to RE and TRRE to RE.

DRRE is the renewable energy consumed directly. It is calculated as the sum of biofuels, waste, geothermal and solar residential energy consumption. The data used come from the balances topic in IEA (2016).

IRRE is defined as the renewable consumption made by using electricity or heat, which has previously been generated by using renewable energies. It is calculated as follows:

$I R R E=r e *$ residential Elec consumption $+r h *$ residential heat consumption 


$$
\begin{aligned}
& r e=\frac{R R E E \text { used in the Elec production }}{\text { Elec production }+ \text { Elec imports }} \\
& r h=\frac{\text { RREE used in the heat production }}{\text { heat production }+ \text { heat imports }}
\end{aligned}
$$

where RREE refers to renewable energies and Elec to electricity.

RREE used in the electricity production is calculated as the sum of biofuels, waste, geothermal, solar PV, wind, hydro and tide energy used to produce electricity. RREE used in heat production is calculated as the sum of biofuels, waste, geothermal and solar thermal energy used to generate heat. The data used come from the electricity and heat topic in IEA (2016).

$$
T R R E=D R R E+I R R E
$$

NRRE is the non-renewable residential energy. It is calculated as the sum of non-renewable energy consumed directly and non-renewable consumption made by using electricity or heat (INRRE). Non-renewable energy consumed directly is calculated as the sum of coal, oil products and natural gas energy consumption. The data used come from the balances topic in IEA (2016). The INRRE is calculated as follows:

$$
\begin{aligned}
& I N R R E=(n r e+i e) * \text { resid. Elec consump. }+(n r h+i h) * \text { resid. heat consump. } \\
& n r e=\frac{\text { NRREE used } \text { in the Elec produc. }}{\text { Elec production }+ \text { Elec imports }} i e=\frac{\text { Elec imports }}{\text { Elec production }+ \text { Elec imports }} \\
& n r h=\frac{\text { NRREE used in the heat produc. }}{\text { heat production }+ \text { heat imports }} i h=\frac{\text { heat imports }}{\text { heat production }+ \text { heat imports }}
\end{aligned}
$$

where NRREE refers to non-renewable energies. NRREE used in the electricity production is calculated as the sum of coal, oil, gas and nuclear energy used to produce electricity. NRREE used in the heat production is calculated as the sum of coal, oil, gas and nuclear energy used to generate heat. All electricity and heat imports are considered non-renewables energy. The data used come from the electricity and heat topic in IEA (2016). 
The world has been divided into 11 regions: the European Union's first 15 members (EU15), new European Union members (EU+), other developed countries (ODC), economies in transition (ET), Central African (CA), Southern African (SA), Middle Eastern and North African (MENA), East Asian (EAS), Southern Asian (SAS), Latin American (LAC) and The Caribbean (CAR) countries. Additionally, four groups have been considered by dividing the world according to GNI in 2013: High income (HI), upper medium income (UMI), lower medium income (LMI) and lower income (LI) countries (See Appendix).

The time period analyzed is 1993-2013, for which there is sufficient data availability for all sample countries.

\section{Results}

\subsection{Residential energy consumption, world status in 2013}

Figure 1 shows TE and RE in 2013 by world regions (colors) and by per capita GNI levels (plots). The area of the outer pie shows the TE in the region, while the area of the inner pie shows RE, the latter being divided into DRRE, IRRE and NRRE. By world regions, it may be highlighted that the highest TE is observed in EAS, ODC and the EU15. It is also worth noting the high RE with respect to TE in CA, and in a lesser proportion in SA. The CA region is also highlighted due to its high percentage of DRRE with respect to RE, which may be related to charcoal consumption. Among the regions with the lower percentage use of this renewable energy are the ET, ODC, MENA and EU regions, which is related mainly to direct and indirect oil fuels consumption. LAC, the EU15 and ODC stand out in IRRE, due to the high production of electricity by using wind, biofuels and hydroelectric energy. Additionally, Figure 1 also shows the TE and 
RE by per capita GNI levels (pies at the bottom of the map). The RE to TE ratio decreases with GNI. Likewise, the ratios of DRRE and IRRE to TE decrease and increase with GNI, respectively.

[Figure 1]

\subsection{Residential energy consumption world growth during 1993- 2013}

Left graph in Figure 2 shows notably lower RE growth trends with respect to TE during 1993-2013 (the growth of RE is nearly half that of TE during the period, as can be seen in Table 1), with the trends of all variables being similar to those shown in the right graph in Figure 2. It is noticed that total TRRE comes mostly from direct sources, although in recent years the share of IRRE energy has increased slightly. Likewise, a very slight difference since 2005 is noticed between DRRE and Biomass and Waste residential energy, therefore other renewables sources used directly in the residential sector have, by the end of 2013, minimal presence and little significance at global level.

[Figure 2]

By regions, Table 1 shows that only the EU+ and ET have reduced TE and RE, with both being close to $4 \%$ in EU15 and 10\% in ODC. The highest TE growth may be observed in EAS, MENA and SAS, while the highest growth in RE is observed in MENA and CA. RE use has less growth than TE in all regions. When considering DRRE and TRRE, the highest values are observed in EU+, EU15, CA and SA, being negative in ET and the DRRE in ODC. It is worth noting the higher TRRE values with respect to DRRE in the EU15, ODC and LAC. The latter two may be related to hydroelectric use, while the first may be related to other RREE used, such as wind or solar. This DRRE and TRRE growth in the EU15 and the EU+ may be related to residential energy policies developed since 2000, with EU legislation being the major driver in policies and measures implemented in the household (Bosseboeuf, 2015). 
Table 1: Growth rate in the period 1993-2013

\begin{tabular}{|c|c|c|c|c|}
\hline & $\begin{array}{c}\text { Total } \\
\text { Energy }\end{array}$ & $\begin{array}{c}\text { Residential } \\
\text { Energy }\end{array}$ & $\begin{array}{c}\text { Direct Renewable } \\
\text { Residential Energy }\end{array}$ & $\begin{array}{c}\text { Total Renewable } \\
\text { Residential Energy }\end{array}$ \\
\hline World & 0.46 & 0.25 & 0.28 & 0.33 \\
\hline EU15 & 0.04 & 0.04 & 0.58 & 0.88 \\
\hline EU+ & -0.02 & -0.07 & 0.86 & 0.95 \\
\hline ET & -0.21 & -0.25 & -0.28 & -0.03 \\
\hline ODC & 0.13 & 0.09 & -0.01 & 0.22 \\
\hline CA & 0.84 & 0.76 & 0.76 & 0.76 \\
\hline SA & 0.63 & 0.60 & 0.54 & 0.56 \\
\hline MENA & 1.25 & 0.91 & 0.01 & 0.09 \\
\hline EAS & 1.46 & 0.39 & 0.09 & 0.14 \\
\hline SAS & 1.07 & 0.59 & 0.29 & 0.17 \\
\hline LAC & 0.68 & 0.32 & 0.02 & 0.28 \\
\hline CAR & 0.77 & 0.34 & 0.28 & \\
\hline
\end{tabular}

Source: Own production from IEA (2016).

The different growth rates by world regions makes evident the change regarding the weight of each of the blocks referring to the total energy demand in the twenty years under consideration (Figure 3). This assessment is based on the unquestionable prevalence that in 1993 the group, composed of the EU15 and ODC, has a consumption totaling $46 \%$ of the total world consumption. This has seen their impact in 2013 reduced to $35 \%$, a reduction that also happened in the economies in transition, from $14 \%$ to $8 \%$. In the opposite context, there has been a significant growth of the TE in EAS, due to the rapid economic growth in the last fifteen years, highlighting among them, and also for the heterogeneity of their size, the People's Republic of China, taking into consideration the important qualitative impacts of Indonesia, Singapore and Vietnam.

Something different occurs if we focus attention on the consumption of energy for residential purposes. The levels reached by the EU15 and ODC jointly, both large consumers in the productive sector, were $34 \%$ in 1993 (as opposed to $46 \%$ for TE in 1993) also showing a reduction in 2013 of about $30 \%$ (as opposed to $35 \%$ for TE in 2013). Meanwhile, the EAS, SAS, CA and MENA regions gain in the percentage share. 
The scenario changes completely when referring to DRRE, where the sum of EAS, SAS and CA alone, reached $81 \%$ in 1993. Figure 3 shows the prevalence of these three blocks in 2013, EAS representing a lower percentage and CA a higher one. The growing percentage for the EU15 (from 3\% to 4\%) may also be noted. Finally, some regional changes have also taken place when considering IRRE. In this case, the ODC prevalence in 1993 , with $47 \%$ of the total, diminishes to $32 \%$ in 2013 , while a notable growth is observed in the EAS percentage, from $4 \%$ to $16 \%$. Likewise, the share of the EU15 also increases from $17 \%$ to $21 \%$ in 2013.

\section{[Figure 3]}

Figure 4 shows the RE and TRRE by per capita GNI levels. RE is proved a practically stable consumption, in $\mathrm{HI}$ and LI, the latter being at substantially lower levels. However, UMI and LMI show a growing trend, although they do not reach the HI level. TRRE shows an almost permanent rate of growth, as much as in LMI as in LI, and much smaller growth in the UMI and HI.

[Figure 4]

\subsection{Total and residential energy consumption per million inhabitants during 1993-} 2013

Figure 5 shows the evolution of TE and RE per million inhabitants by world regions in the period 1993-2013. Through the time period, the total energy consumption by inhabitants is around 1,250 Ktoe/million inhabitants, showing a slightly positive trend. Above the world trend, it highlights the ODC TE per capita consumption, even though it has had a negative trend since the beginning of 2000. Above the world trend, ET and EU regions are also highlighted. Below the world trend, it is worth mentioning the positive TE growth in the EAS region, and to a lower extent in MENA countries. The positive world TE per capita consumption contrasts with the almost constant RE 
per inhabitants' world trend. Above this trend are again ODC, ET and EU regions, although the differences among them, shown in the first graph of Figure 5, are now less. Above this trend, the EAS region again shows a positive, although less intense, growth. This pattern of behavior changes radically when the renewable residential energy used (in per capita term) is considered, either for DRRE or TRRE. Above the world trend stand CA, SA and EAS, with an almost constant trend, while below world value stand out the positive evolution in EU regions, especially in the latter years of the considered period and when considering TRRE.

[Figure 5]

Notable energy consumption differences are also shown when countries are grouped by per capita GNI levels. Figure 6 shows that the highest TE per capita consumption is conducted, with a remarkable difference, by high income countries, its trend being almost constant. Likewise, the first graph in Figure 6 also shows that UMI countries present a notable growing trend, especially since 2002. This positive trend is also shown for the residential energy per capita consumption in UMI countries, but to a much lower extent. Once again, the HI countries stand out above in the graph, but this time with a clear negative trend. It can be noted again that the pattern of behavior changes radically when the DRRE and TRRE (in per capita terms) are considered. LI have the higher per capita consumption values, while HI countries have the lesser. Nevertheless, it can be appreciated that this last group of countries has a positive growth trend, the growth in the TRRE being especially remarkable.

[Figure 6] 


\subsection{Residential energy consumption per GDP (PPP) during 1993- 2013}

Figure 7 shows the evolution of RE in terms of GDP (PPP). The world trend is decreasing for RE, and also for renewable RE. Those regions with higher energy consumption per GDP (CA, SA, SAS and EAS) also have the highest decreasing trends during the whole period. Lesser RE and renewable RE per GDP are obtained for the EU15, EU+ and ODC. These regional trends are almost constant. Nevertheless, it may be noted that EU15 countries have a positive growth in renewable RE consumption per GDP, being more remarkable when considering TRRE energy. The decreasing trend for RE per GDP is also shown for all economic groups by per capita GNI, the highest value being obtained for LI and LMI groups. This decreasing trend is also observed for renewable RE per GDP for LI, LMI and UMI, but not for HI countries, which show constant values.

\subsection{Residential energy consumption ratios during 1993- 2013}

Figure 8 shows the ratio of RE to TE and DRRE and TRRE to RE. Upper graphs show the ratio by world regions, and graphs at the bottom by per capita GNI level. World RE represents around $25 \%$ of TE, with a decreasing trend during the period. The EU15 maintain this ratio during the whole period, while ODC, MENA and LCA have lower values (less than 20\%). CA, SA and SAS have values higher than $35 \%$ and it is worth noting the negative trend observed in the EAS group (from $37 \%$ to $21 \%$ approximately). Figure 8 also shows that around $40 \%$ of RE in the world is from DRRE, this percentage being constant during the whole period. Nevertheless, many differences are observed among groups. The CA percentage is nearly $98 \%$, SA, SAS and EAS have decreasing percentage values of between $60-80 \%$, LCA has values similar to world 
values, but slightly decreasing, MENA has decreasing values around 20\%, and, ODC and ET have the lowest values (below 10\%). The only two regions with a positive trend are the EU15 and EU+. Both regions have initial values around 10\%, ending the period with values of approximately $17 \%$ and $21 \%$, respectively. The same pattern is observed for TRRE with respect to RE, but with a more remarkable growth for both EU regions. Finally, Figure 8 shows notable differences in the ratio by per capita GNI level. RE with respect to TE is around $78 \%, 45 \%, 24 \%$ and $20 \%$ in LI, LMI, UMI and $\mathrm{HI}$ respectively, slightly decreasing in all cases except for HI, which is constant. Renewable RE with respect to RE is $98 \%, 75 \%, 50 \%$ and $10 \%$ in LI, LMI, UMI and HI respectively, being constant in LI and LMI, decreasing in UMI and increasing in HI, especially for TRRE.

\section{Conclusion and Policy implications}

The residential energy sector is crucial to achieving $\mathrm{CO}_{2}$ emission reductions as it has an important energy-saving potential and its environmental controls are difficult to displace to other countries. Therefore residential energy policies may be more efficient than in other sectors.

At regional level, notable differences are observed among the main regions worldwide. Therefore, a varied, and not a unique, global energy policy should be recommended, and applied. In 2013, EAS had the highest RE, followed by ODC, SAS and the EU15. Therefore, these regions should make the greatest effort to reduce energy consumption. Regional differences are also observed in the renewable energies used, representing DRRE about $40 \%$ of RE globally. The lower percentages of DRRE are found in the ET, ODC, MENA and EU regions. It is necessary that efforts are made to change the energy mix, especially in these last regions, by discouraging the use of fuel, 
and promoting RREE. The EU regions are the sole regions which have a renewable percentage positive trend, which may be related to their renewable energy policy based on the development of different national action plans, in which each country explains how they intend to meet their legally binding 2020 targets under the European Renewable Energy Directive (2009/28/EC), including individual renewable energy targets for the electricity, heating and cooling, and transport sectors. In that regard, the European target of achieving $20 \%$ of RE by 2020 has been very helpful. Nevertheless, the low values of DRRE in EU regions make it desirable to be more profound in their energy policies. Additionally, by per capita GNI levels, the HI countries should make the greatest efforts to reduce the use of NRRE. The highest RE renewables are observed in LI, especially in CA and SA. Nevertheless it is important to point out that the use of charcoal may not be especially suitable for health when this is used in large cities. Therefore, the development of energy projects related to the expansion and reinforcement of the electricity service in the poorest areas, as for example those developed in Colombia, are recommended, especially the establishment of financial support funds to finance renewable power generation projects in non-interconnected areas.

During 1993-2013, RE has grown to nearly half of TE globally, but only the EU+ and ET have reduced it. The highest RE growth is observed in MENA, SAS, SA and CA. Thus, the EU15 and ODC have jointly reduced their world share in energy consumption through residential uses, although it still represented $30 \%$ in 2013 . The scenario changes completely when referring to DRRE, where just the sum of EAS, SAS and CA, reached around 80\% of global DRRE in 2013. The EU15 and CA are the only regions which increased their world share. The world distribution by regions of IRRE 
has also changed. The ODC prevalence had decreased to $32 \%$ in 2013 , while the EAS and EU15 percentages have increased.

Jointly (direct and indirect RRE), the highest growth is observed in the EU+ and EU15, which may be related to residential energy, electricity and heat and cooling policies, mainly developed since 2000. The European Directive of 2001 stated that the renewable electricity of all European member states should reach a common target of $21 \%$ of total electricity consumption by the end of 2010 . Since then, the European countries have started to develop some policies to promote renewable electricity. Among them, some countries, such as Germany, promoted renewable energy in residential buildings, solar PV installation in residential buildings for instance. In addition, EU authorities have also promoted the use of renewable energy sources for heating and cooling uses. In 2006, the European Parliament adopted a report suggesting that the renewable energy sources for heating and cooling should be increased up to $20 \%$ by 2020 , thus public promotion has also been done to promote this type of renewable energy. In the case of the use of renewable energy to heat water for example, public promotion is not only done through grants or tax incentives but also by establishing legal rules. For example, Germany stipulated in 2008 a 15\% minimum use of renewable energy for all new buildings. Likewise, in Spain, solar thermal energy has been mandatory since 2006 for all Domestic Hot Water installations in some buildings.

On the other hand, it seems that EAS is promoting the use of RREE for electricity, but not directly in the residential sector. China for example had an accelerated growth in hydroelectricity, solar PV and wind. Nevertheless, nearly all biomass is used in traditional forms for cooking (IRENA, 2014). Therefore, it is appropriate to promote the use of DRRE in EAS. 
In per capita terms, the EU, ODC and ET have higher and decreasing RE, while SAS and EAS have lower but increasing values. It is again worth underlining the growing trend of DRRE and TRRE in the EU and to a lesser extent in ODC. Therefore, the residential efficiency policies are having good results in the more developed countries. In this sense, some authors find a positive impact of the EU energy efficiency policies on energy intensity, which may be related especially to a policy mix based on financial incentives and energy performance standards rather than a single policy (Bigano et al. 2011; Filippini et al., 2014b). Likewise, in the US, the federal government has set appliance standards and provided financial incentives. Meanwhile the local governments have also created their own building energy codes (Nejat et al; 2015). Therefore, it would be appropriate to translate this mix of renewable policies to other world regions, especially to other ODC, ET, EAS and SAS countries.

In GDP terms, the RE world trend is decreasing. Lower RE and renewable RE per GDP are obtained in the EU15, EU+ and ODC, with the trends of these regions being almost constant. By per capita GNI groups, it seems that RE is decreasing as GDP grows, but to a lower value, which tend to be preserved. Therefore, it is considered important to promote renewable energies in the residential sector to reduce $\mathrm{CO}_{2}$ emissions, it being possible to promote either the direct use of RREE or their use for generating electricity or heat.

\section{ACKNOWLEDGMENTS}

The first and third authors acknowledge the financial support received from the ECO2014-56399-R Project of the Spanish Ministry of Economy and Competitiveness and from the Cátedra de la Economía de la Energía y del Medio Ambiente (Chair of Energy and Environmental Economics) of the Fundació Roger Torné. 


\section{References}

Auffhammer, M., Wolfram, C.D. (2014). Powering up China: Income distributions and residential electricity consumption. The American Economic Review, 104(5), 575-580.

Bigano, A., Arigoni Ortiz, R., Markandya, A., Menichetti, E., Pierfederici, R. (2011). The linkages between energy efficiency and security of energy supply in Europe. Chapter 4 in Galarraga, I., González-Eguino, M., Markandya, A.: Handbook of sustainable energy. Northampton: Edward Elgar Publishing Ltd

Bosseboeuf, D. (2009). Energy Efficiency Trends and Policies in the Household and Tertiary Sectors. An Analysis Based on the ODYSSEE and MURE Databases. ODYSSEE-MURE project report.

Bridge, G., Bouzarovski, S., Bradshaw, M., Eyre, N. (2013). Geographies of energy transition: space, place and the low-carbon economy. Energy Policy 53, 331-340

Burleson, E. (2016). Paris Agreement and Consensus to Address Climate Challenge. ASIL INSIGHT, Forthcoming.

Filippini, M., Hunt, L., Zoric, J. (2014a). Residential energy demand and energyefficiency of the EU member states: a stochastic frontier approach. Energy Policy, 69(June), 73-81.

Filippini, M., Hunt, L. C., Zorić, J. (2014b). Impact of energy policy instruments on the estimated level of underlying energy efficiency in the EU residential sector. Energy Policy, 69, 73-81.

Gertler, P. J., Shelef, O., Wolfram, C.D., Fuchs, A. (2016). The Demand for EnergyUsing Assets among the World's Rising Middle Classes. The American Economic Review, 106(6), 1366-1401.

IEA (2011). 25 Energy efficiency policy recommendations 2011 Update. International Energy Agency.

IEA (2016). Statistics Report. International Energy Agency, OECD/IEA, Paris (France).

IRENA (2014). Renewable Energy Prospects: China. REmap 2030 analysis. IRENA, Abu Dhabi.

Jamasb, T., Meier, H. (2010). Household energy expenditure and income groups: evidence from Great Britain. Cambridge: University of Cambridge, Faculty of Economics.

Kanemoto, K., Moran, D; Lenzen, M; Geschke, A. (2014). International trade undermines national emission reduction targets: New evidence from air pollution. Global Environmental Change, 24, 52-59. 
Lau, L.S., Choong, C.K; Eng, Y.K. (2014). Investigation of the environmental Kuznets curve for carbon emissions in Malaysia: Do foreign direct investment and trade matter? Energy Policy, 68, 490-497.

Lee, S; Lee, B. (2014). The influence of urban form on GHG emissions in the U.S. household sector. Energy Policy, 68:534-49.

Mundaca, L., Markandya, A., Nørgaard, J. (2013). Walking away from a low-carbon economy? Recent and historical trends using a regional decomposition analysis. Energy Policy, 61, 1471-1480.

Nejat, P., Jomehzadeh, F., Taheri, M. M., Gohari, M., Majid, M. Z. A. (2015). A global review of energy consumption, $\mathrm{CO} 2$ emissions and policy in the residential sector (with an overview of the top ten CO 2 emitting countries). Renewable and sustainable energy reviews, 43, 843-862.

Štreimikienè, D. (2014). Residential energy consumption trends, main drivers and policies in Lithuania. Renewable and Sustainable Energy Reviews, 35, 285-293.

Wolfram, C., Shelef, O., Gertler, P. (2012). How will energy demand develop in the developing world? The Journal of Economic Perspectives, 26(1), 119-137

Zhao, X., Li, N., Ma, C. (2012). Residential energy consumption in urban China: a decomposition analysis. Energy Policy, 41, 644-653. 


\section{Appendix}

\begin{tabular}{|c|c|c|c|}
\hline Region & \multicolumn{3}{|c|}{ Countries } \\
\hline $\begin{array}{c}\text { CA: Central } \\
\text { Africa }\end{array}$ & $\begin{array}{l}\text { Benin } \\
\text { Cameroon } \\
\text { Congo } \\
\text { Congo, Democratic Republic of } \\
\text { Ivory Coast }\end{array}$ & $\begin{array}{l}\text { Eritrea } \\
\text { Ethiopia } \\
\text { Gabon } \\
\text { Ghana } \\
\text { Kenya }\end{array}$ & $\begin{array}{l}\text { Nigeria } \\
\text { Senegal } \\
\text { Tanzania, United Republic of } \\
\text { Togo }\end{array}$ \\
\hline $\begin{array}{l}\text { CAR: the } \\
\text { Caribbean }\end{array}$ & $\begin{array}{l}\text { Cuba } \\
\text { Dominican Republic }\end{array}$ & $\begin{array}{l}\text { Haiti } \\
\text { Jamaica }\end{array}$ & Trinidad and Tobago \\
\hline $\begin{array}{l}\text { EAS: East } \\
\text { Asia }\end{array}$ & $\begin{array}{l}\text { Brunei Darussalam } \\
\text { Cambodia } \\
\text { China, People's Republic of } \\
\text { Chinese Taipei } \\
\text { Hong Kong, China } \\
\end{array}$ & $\begin{array}{l}\text { Indonesia } \\
\text { Korea } \\
\text { Mongolia } \\
\text { Myanmar } \\
\text { Philippines } \\
\end{array}$ & $\begin{array}{l}\text { Singapore } \\
\text { Thailand } \\
\text { Vietnam }\end{array}$ \\
\hline $\begin{array}{l}\text { ET: } \\
\text { Economies } \\
\text { in } \\
\text { Transition }\end{array}$ & $\begin{array}{l}\text { Albania } \\
\text { Armenia } \\
\text { Azerbaijan } \\
\text { Belarus } \\
\text { Bosnia and Herzegovina } \\
\text { Georgia } \\
\end{array}$ & $\begin{array}{l}\text { Kazakhstan } \\
\text { Kyrgyzstan } \\
\text { Moldova, Republic of } \\
\text { Montenegro } \\
\text { Russian Federation } \\
\text { Serbia }\end{array}$ & $\begin{array}{l}\text { Tajikistan } \\
\text { Turkmenistan } \\
\text { Ukraine } \\
\text { Uzbekistan }\end{array}$ \\
\hline $\begin{array}{l}\text { EU+: New } \\
\text { European } \\
\text { Union } \\
\text { members }\end{array}$ & $\begin{array}{l}\text { Bulgaria } \\
\text { Croatia } \\
\text { Cyprus } \\
\text { Czech Republic } \\
\text { Estonia } \\
\end{array}$ & $\begin{array}{l}\text { Hungary } \\
\text { Latvia } \\
\text { Lithuania } \\
\text { Malta } \\
\text { Poland } \\
\end{array}$ & $\begin{array}{l}\text { Romania } \\
\text { Slovak Republic } \\
\text { Slovenia }\end{array}$ \\
\hline $\begin{array}{l}\text { EU15: } \\
\text { European } \\
\text { Union-15 } \\
\text { countries }\end{array}$ & $\begin{array}{l}\text { Austria } \\
\text { Belgium } \\
\text { Denmark } \\
\text { Finland } \\
\text { France } \\
\end{array}$ & $\begin{array}{l}\text { Germany } \\
\text { Greece } \\
\text { Ireland } \\
\text { Italy } \\
\text { Luxembourg }\end{array}$ & $\begin{array}{l}\text { Netherlands } \\
\text { Portugal } \\
\text { Spain } \\
\text { Sweden } \\
\text { United Kingdom }\end{array}$ \\
\hline $\begin{array}{l}\text { LAC: Latin } \\
\text { America }\end{array}$ & $\begin{array}{l}\text { Argentina } \\
\text { Bolivia } \\
\text { Brazil } \\
\text { Chile } \\
\text { Colombia } \\
\text { Costa Rica } \\
\end{array}$ & $\begin{array}{l}\text { Ecuador } \\
\text { El Salvador } \\
\text { Guatemala } \\
\text { Honduras } \\
\text { Mexico } \\
\text { Nicaragua } \\
\end{array}$ & $\begin{array}{l}\text { Panama } \\
\text { Paraguay } \\
\text { Peru } \\
\text { Uruguay } \\
\text { Venezuela }\end{array}$ \\
\hline $\begin{array}{l}\text { MENA: } \\
\text { Middle East } \\
\text { and North } \\
\text { Africa }\end{array}$ & \begin{tabular}{|l} 
Algeria \\
Bahrain \\
Egypt \\
Iraq \\
Israel \\
Jordan \\
Kuwait \\
\end{tabular} & $\begin{array}{l}\text { Lebanon } \\
\text { Libya } \\
\text { Morocco } \\
\text { Oman } \\
\text { Qatar } \\
\text { Saudi Arabia } \\
\text { Sudan }\end{array}$ & $\begin{array}{l}\text { Syrian Arab Republic } \\
\text { Tunisia } \\
\text { Turkey } \\
\text { United Arab Emirates } \\
\text { Yemen }\end{array}$ \\
\hline $\begin{array}{l}\text { ODC: Other } \\
\text { Developed } \\
\text { Countries }\end{array}$ & $\begin{array}{l}\text { Australia } \\
\text { Canada } \\
\text { Iceland }\end{array}$ & $\begin{array}{l}\text { Japan } \\
\text { New Zealand } \\
\text { Norway }\end{array}$ & $\begin{array}{l}\text { Switzerland } \\
\text { United States }\end{array}$ \\
\hline $\begin{array}{c}\text { SA: } \\
\text { Southern } \\
\text { Africa }\end{array}$ & $\begin{array}{l}\text { Angola } \\
\text { Botswana } \\
\text { Mauritius }\end{array}$ & $\begin{array}{l}\text { Mozambique } \\
\text { Namibia } \\
\text { South Africa }\end{array}$ & $\begin{array}{l}\text { Zambia } \\
\text { Zimbabwe }\end{array}$ \\
\hline $\begin{array}{l}\text { SAS: South } \\
\text { Asia }\end{array}$ & $\begin{array}{l}\text { Bangladesh } \\
\text { India }\end{array}$ & $\begin{array}{l}\text { Iran, Islamic Republic of } \\
\text { Nepal }\end{array}$ & $\begin{array}{l}\text { Pakistan } \\
\text { Sri Lanka }\end{array}$ \\
\hline
\end{tabular}




\begin{tabular}{|c|c|c|c|}
\hline Income & \multicolumn{3}{|c|}{ Countries } \\
\hline \multirow{16}{*}{$\begin{array}{l}\text { HI: High } \\
\text { Income }\end{array}$} & Austria & Hong Kong, China & Poland \\
\hline & Bahrain & Iceland & Portugal \\
\hline & Belgium & Ireland & Qatar \\
\hline & Brunei Darussalam & Israel & Russian Federation \\
\hline & Canada & Italy & Saudi Arabia \\
\hline & Chile & Japan & Singapore \\
\hline & Chinese Taipei & Korea & Slovak Republic \\
\hline & Croatia & Kuwait & Slovenia \\
\hline & Cyprus & Latvia & Spain \\
\hline & Czech Republic & Lithuania & Sweden \\
\hline & Denmark & Luxembourg & Switzerland \\
\hline & Estonia & Malta & Trinidad and Tobago \\
\hline & Finland & Netherlands & United Arab Emirates \\
\hline & France & New Zealand & United Kingdom \\
\hline & Germany & Norway & United States \\
\hline & Greece & Oman & Uruguay \\
\hline \multirow{14}{*}{$\begin{array}{l}\text { UMI: } \\
\text { Upper } \\
\text { Medium } \\
\text { Income }\end{array}$} & Albania & Cuba & Mexico \\
\hline & Algeria & Dominican Republic & Montenegro \\
\hline & Angola & Ecuador & Namibia \\
\hline & Argentina & Gabon & Panama \\
\hline & Australia & Hungary & Peru \\
\hline & Azerbaijan & Iran, Islamic Republic of & Romania \\
\hline & Belarus & Iraq & Serbia \\
\hline & Bosnia and Herzegovina & Jamaica & South Africa \\
\hline & Botswana & Jordan & Thailand \\
\hline & Brazil & Kazakhstan & Tunisia \\
\hline & Bulgaria & Lebanon & Turkey \\
\hline & China, People's Republic of & Libya & Turkmenistan \\
\hline & Colombia & Malaysia & Venezuela \\
\hline & Costa Rica & Mauritius & \\
\hline \multirow{10}{*}{$\begin{array}{l}\text { LMI: } \\
\text { Lower } \\
\text { Medium } \\
\text { Income }\end{array}$} & Armenia & Honduras & Paraguay \\
\hline & Bolivia & India & Philippines \\
\hline & Cameroon & Indonesia & Senegal \\
\hline & Congo & Kyrgyzstan & Sri Lanka \\
\hline & Ivory Coast & Moldova, Republic of & Sudan \\
\hline & Egypt & Mongolia & Syrian Arab Republic \\
\hline & El Salvador & Morocco & Ukraine \\
\hline & Georgia & Nicaragua & Uzbekistan \\
\hline & Ghana & Nigeria & Viet Nam \\
\hline & Guatemala & Pakistan & \\
\hline \multirow{5}{*}{$\begin{array}{l}\text { LI: Low } \\
\text { Income }\end{array}$} & Bangladesh & Ethiopia & Nepal \\
\hline & Benin & Haiti & Tajikistan \\
\hline & Cambodia & Kenya & Togo \\
\hline & Congo, Democratic Republic of & Mozambique & Zimbabwe \\
\hline & Eritrea & Myanmar & \\
\hline
\end{tabular}


Figure 1: Total and residential energy consumption in 2013.

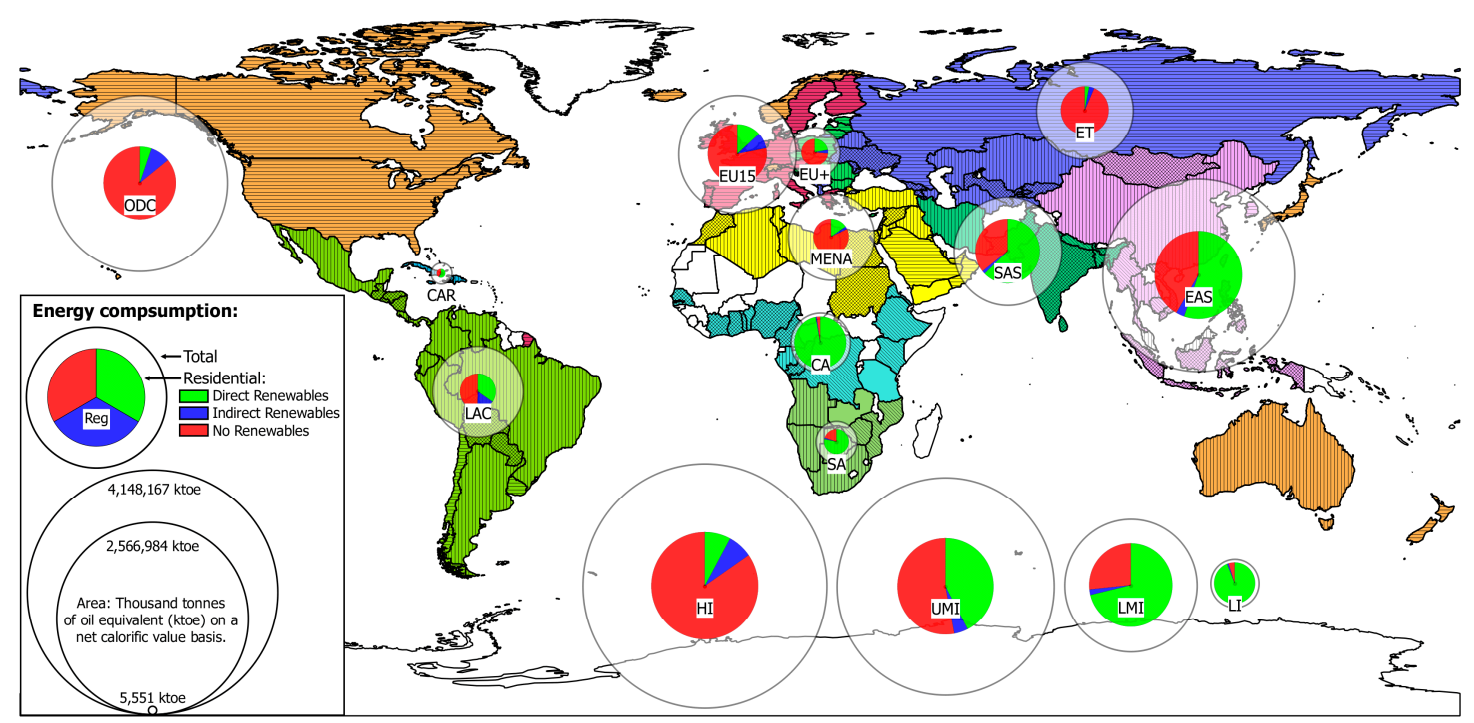

$\square$ CA: Central Africa
CAR: the Caribbean
$\square$ EU+: New European Union member States $\square$ ODC: other developed countries $\begin{aligned} & \text { OLropean Union-15 countries } \\ & \text { EAS: East Asia }\end{aligned}$ SA: Southern Africa
$\square$ LAC: Latin America
ET: Economies in transition $\square$ MENA: Middle East and North Africa

Source: Own production from IEA (2016). Maps (C) EuroGeographics for the administrative boundaries.

Figure 2. Total and Residential Energy Consumption

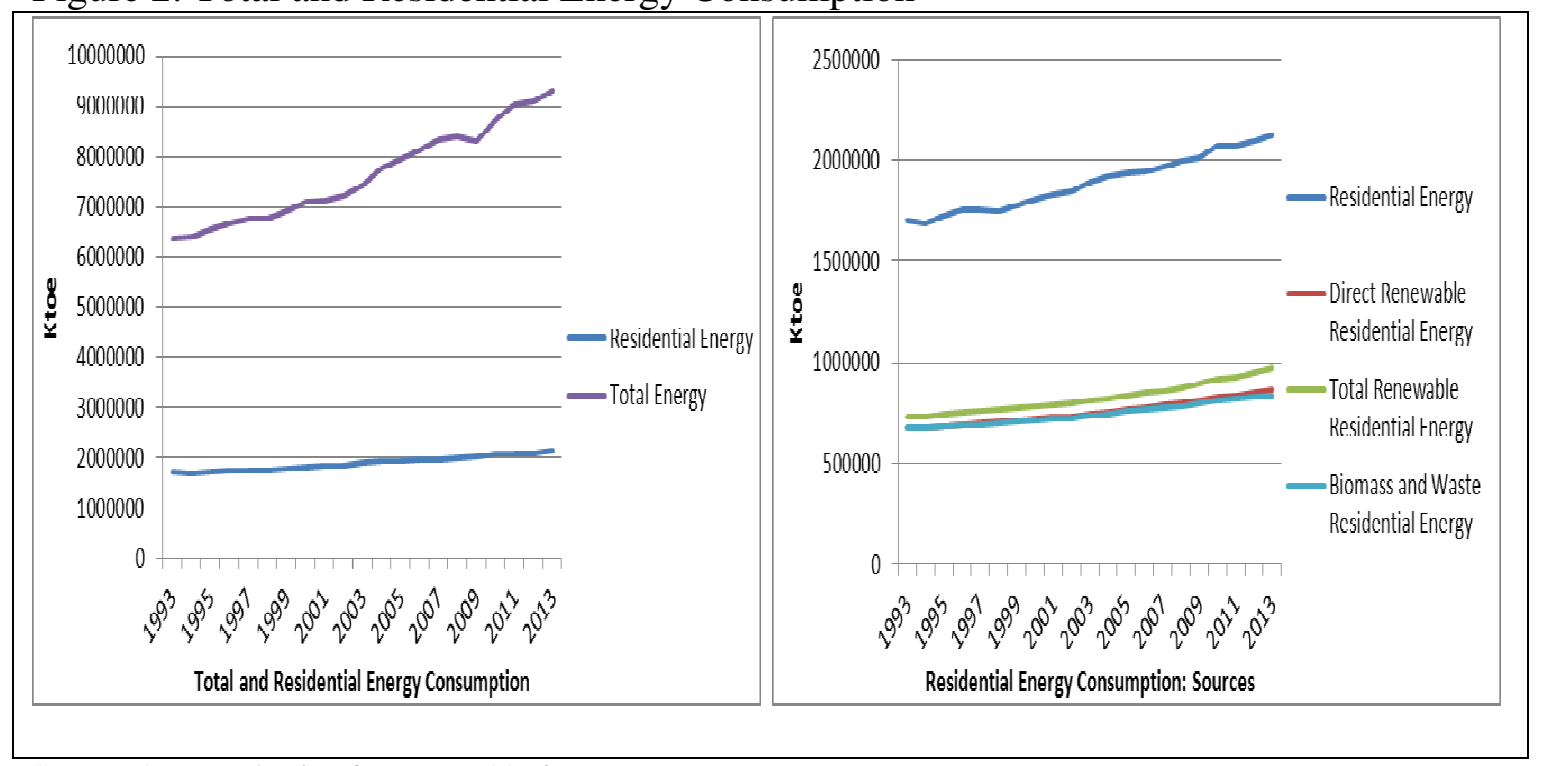

Source: Own production from IEA (2016). 
Figure 3: Total and Residential Energy Consumption: World Regions 1993-2013

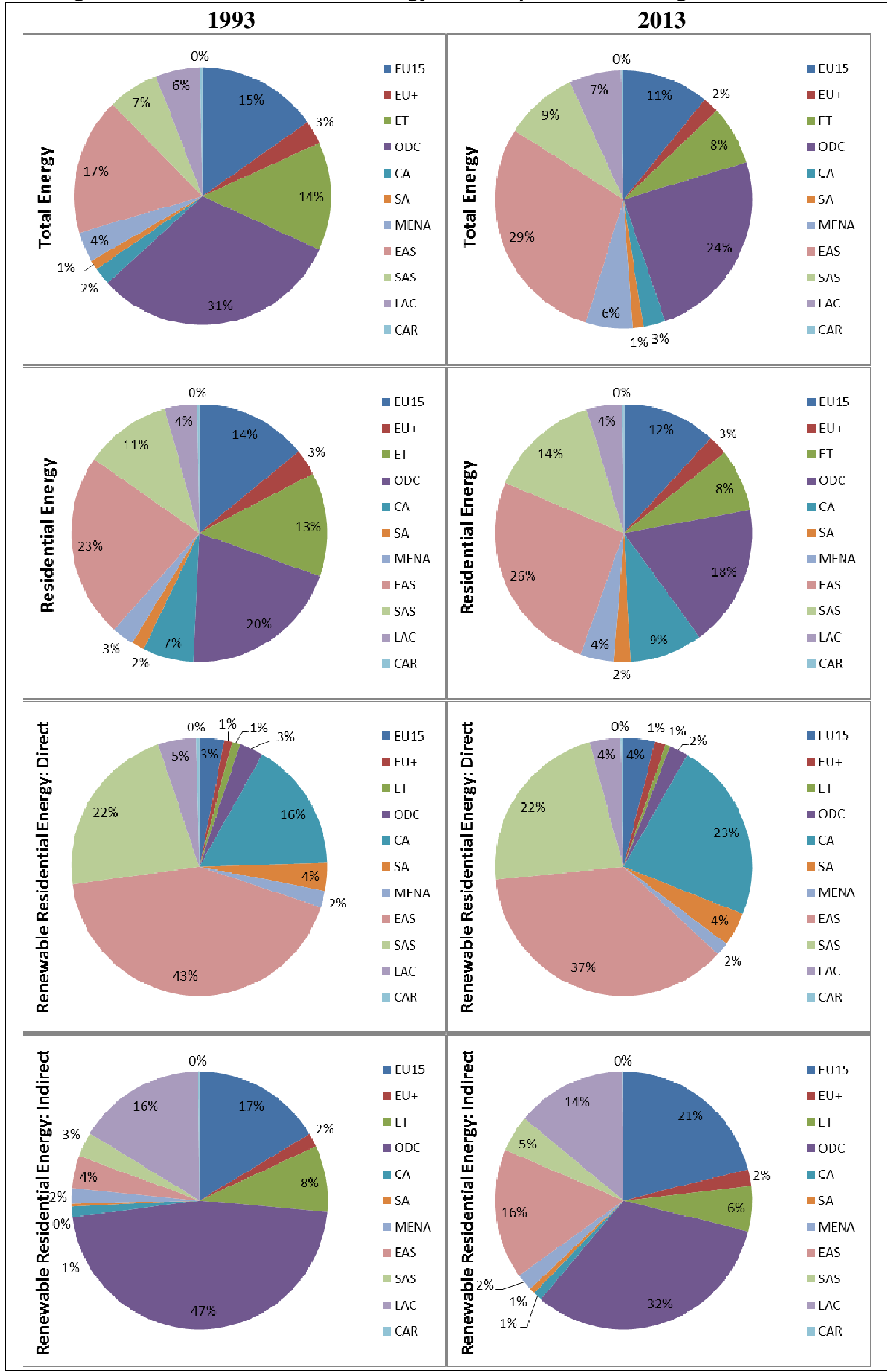

Source: Own production from IEA (2016). 
Figure 4. Residential energy consumption trends (1993-2013). Economies by per capita GNI levels in 2013

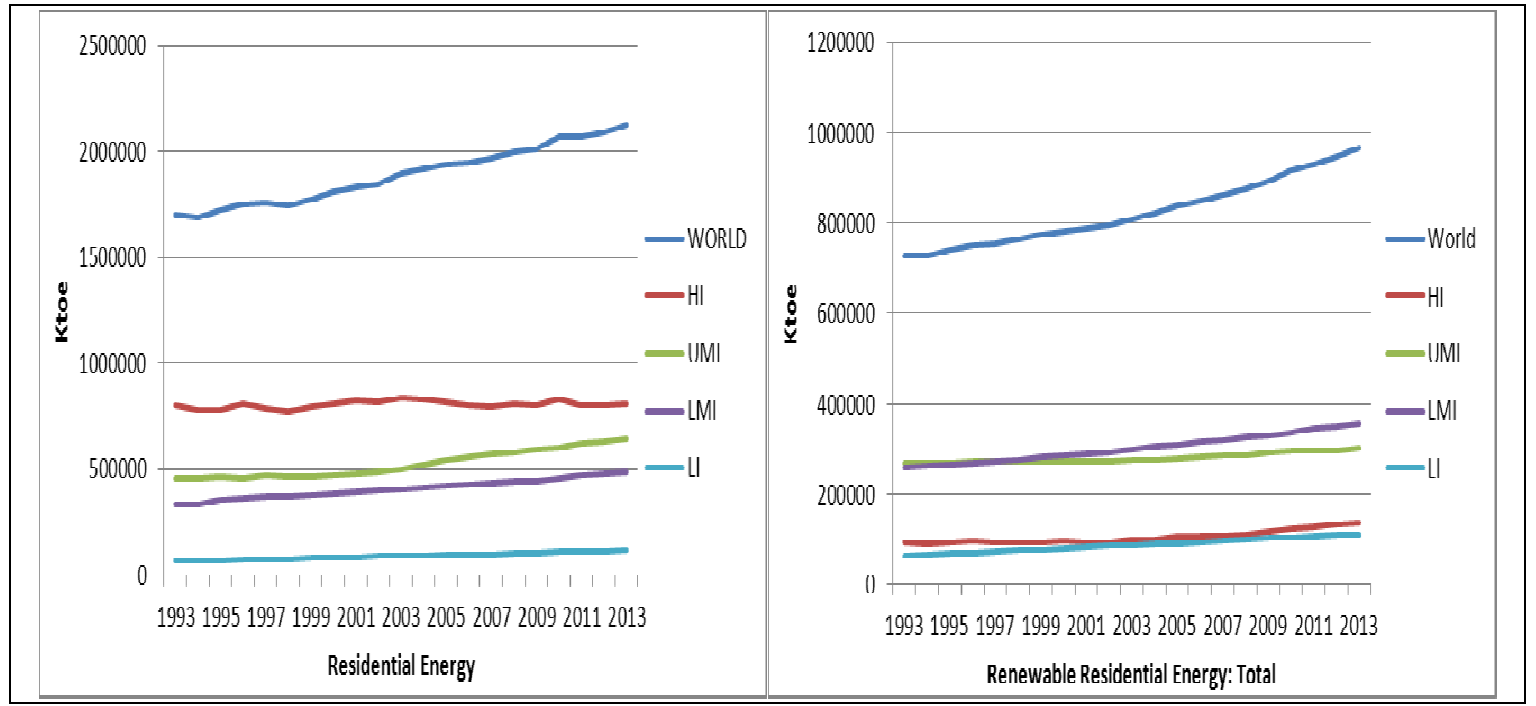

Source: Own production from IEA (2016).

Figure 5: Total and Residential energy per capita consumption trends (1993-2013). World Regions

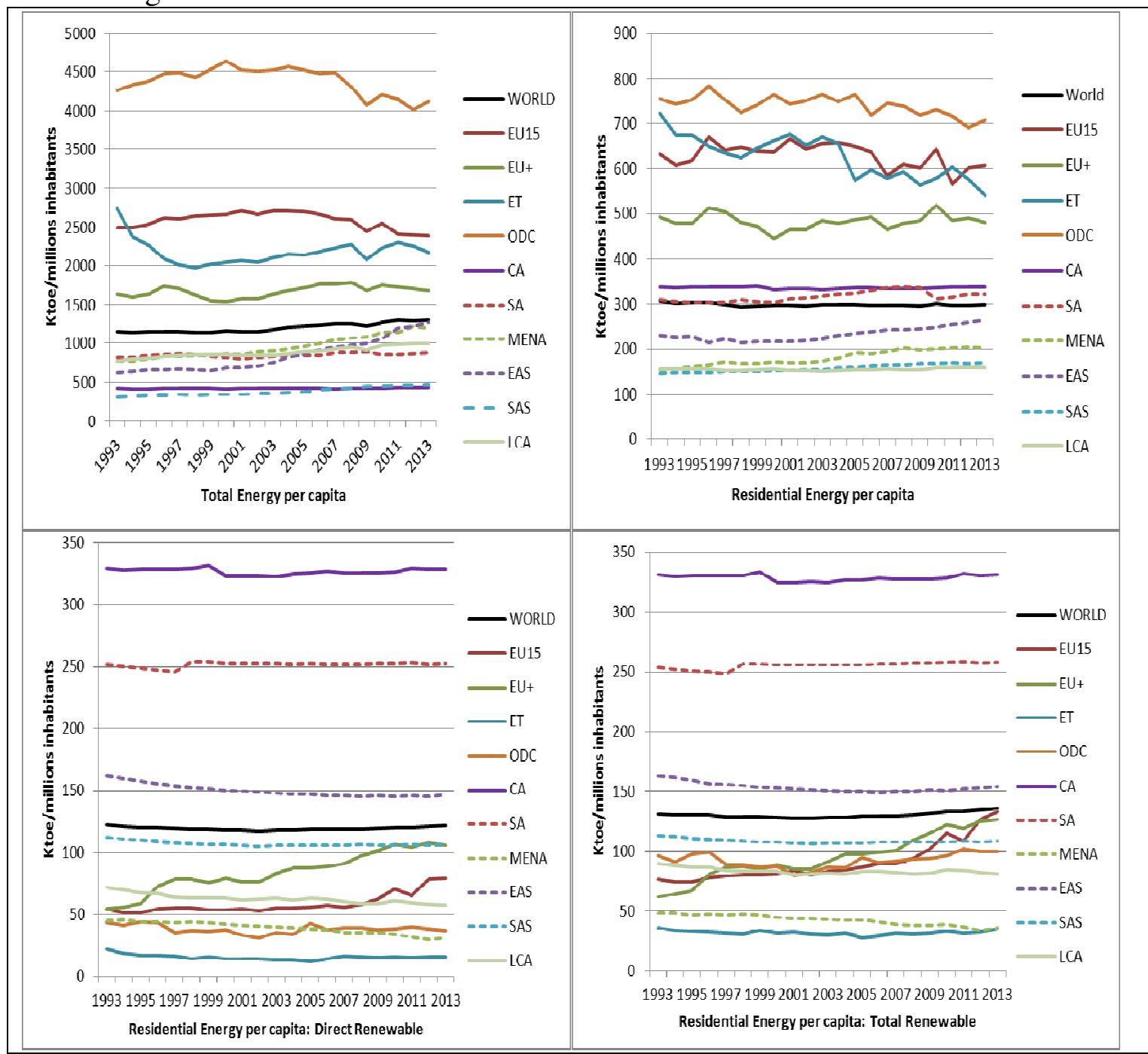

Source: Own production from IEA (2016) 
Figure 6: Total and Residential energy per capita consumption trends (1993-2013). Economies by per capita GNI levels in 2013

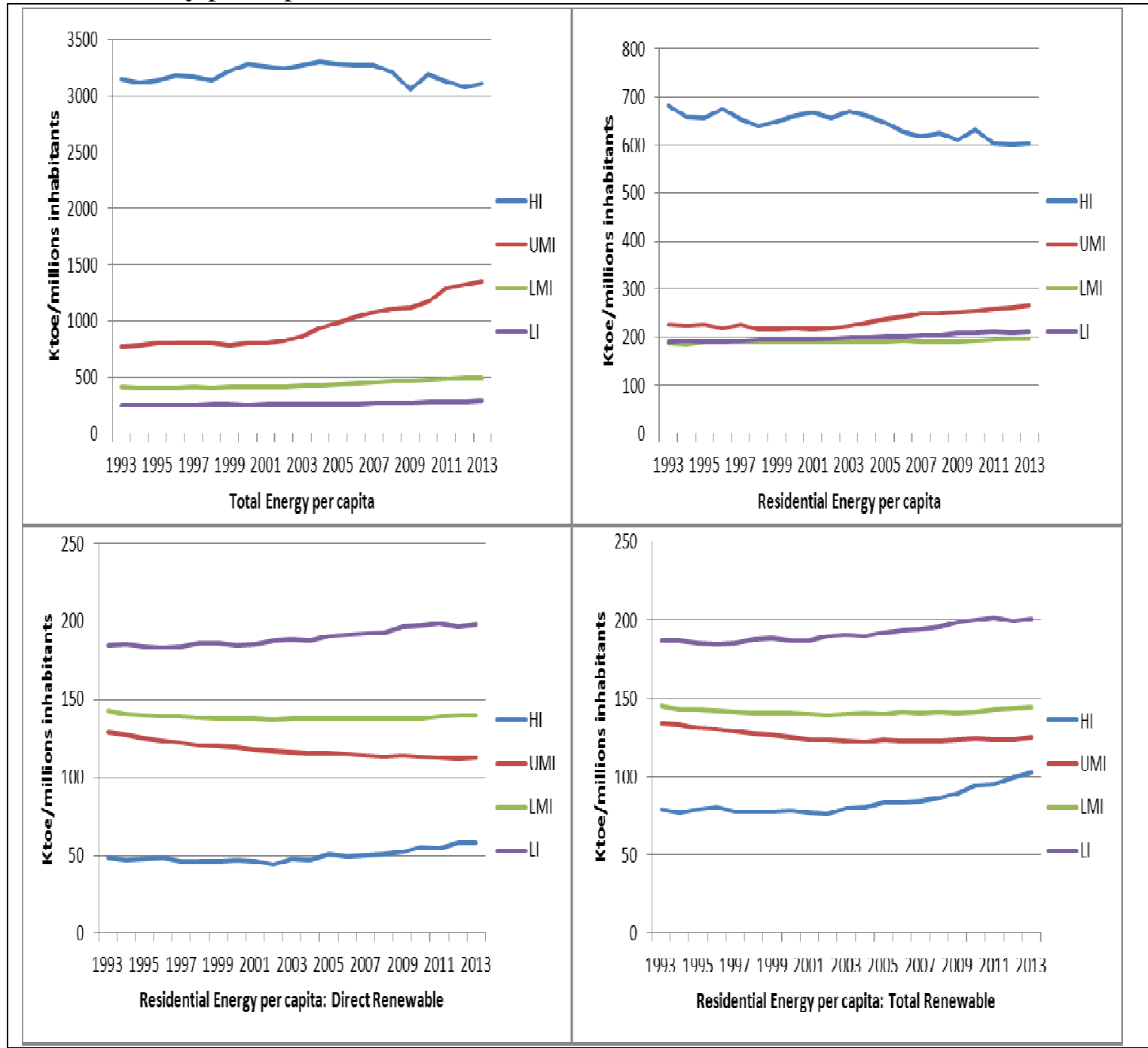

Source: Own production from IEA (2016) 
Figure 7: Residential energy per GDP (PPP) trends (1993-2013). World Regions and Economies by per capita GNI in 2013

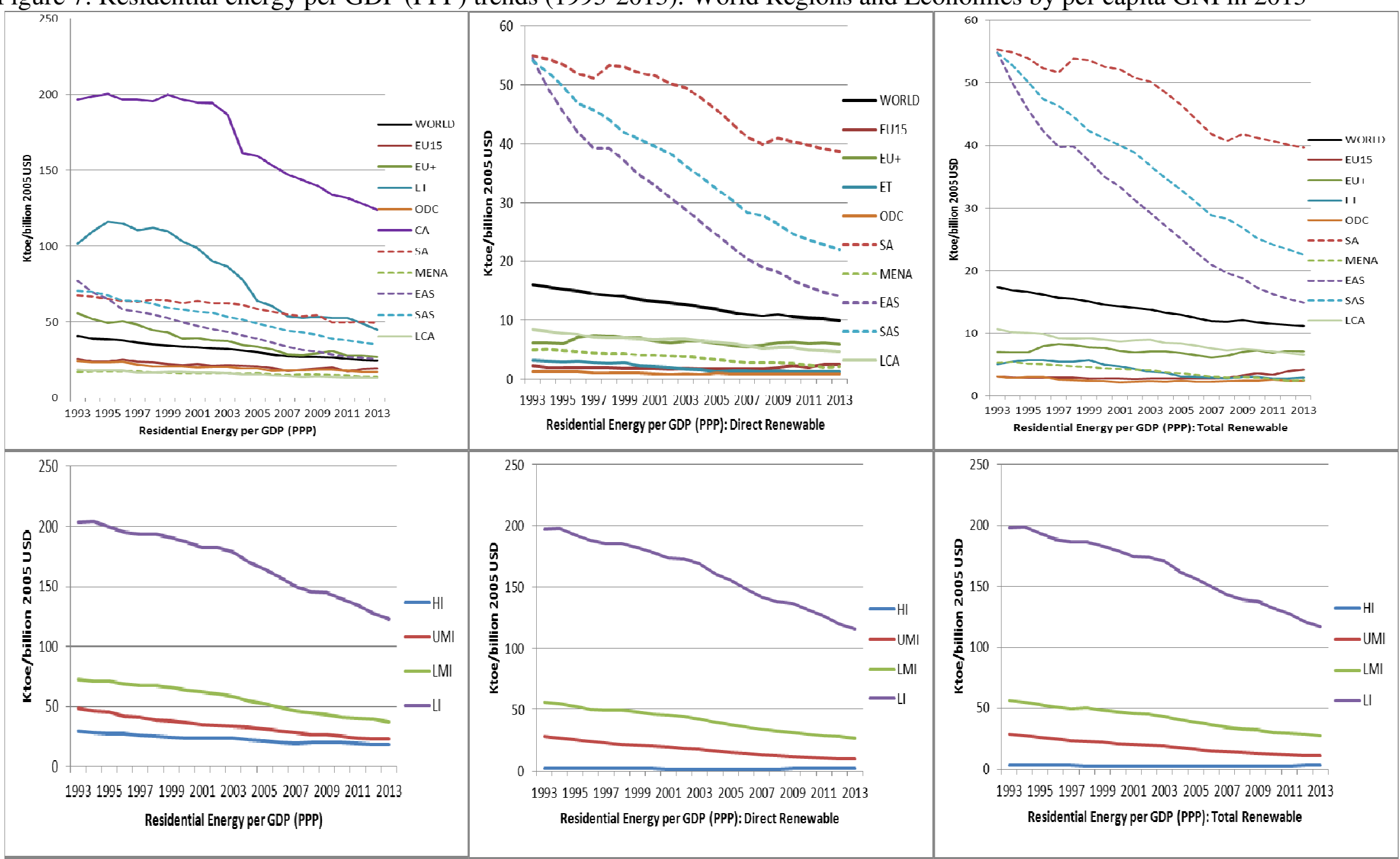

Source: Own production from IEA (2016). *CA region values do not appear in the second and third upper graphs as its values for renewable energy consumption are very similar to total residential energy and therefore much higher than in other regions. 
Figure 8: Residential Energy ratios by World Regions and by per capita GNI level in 2013
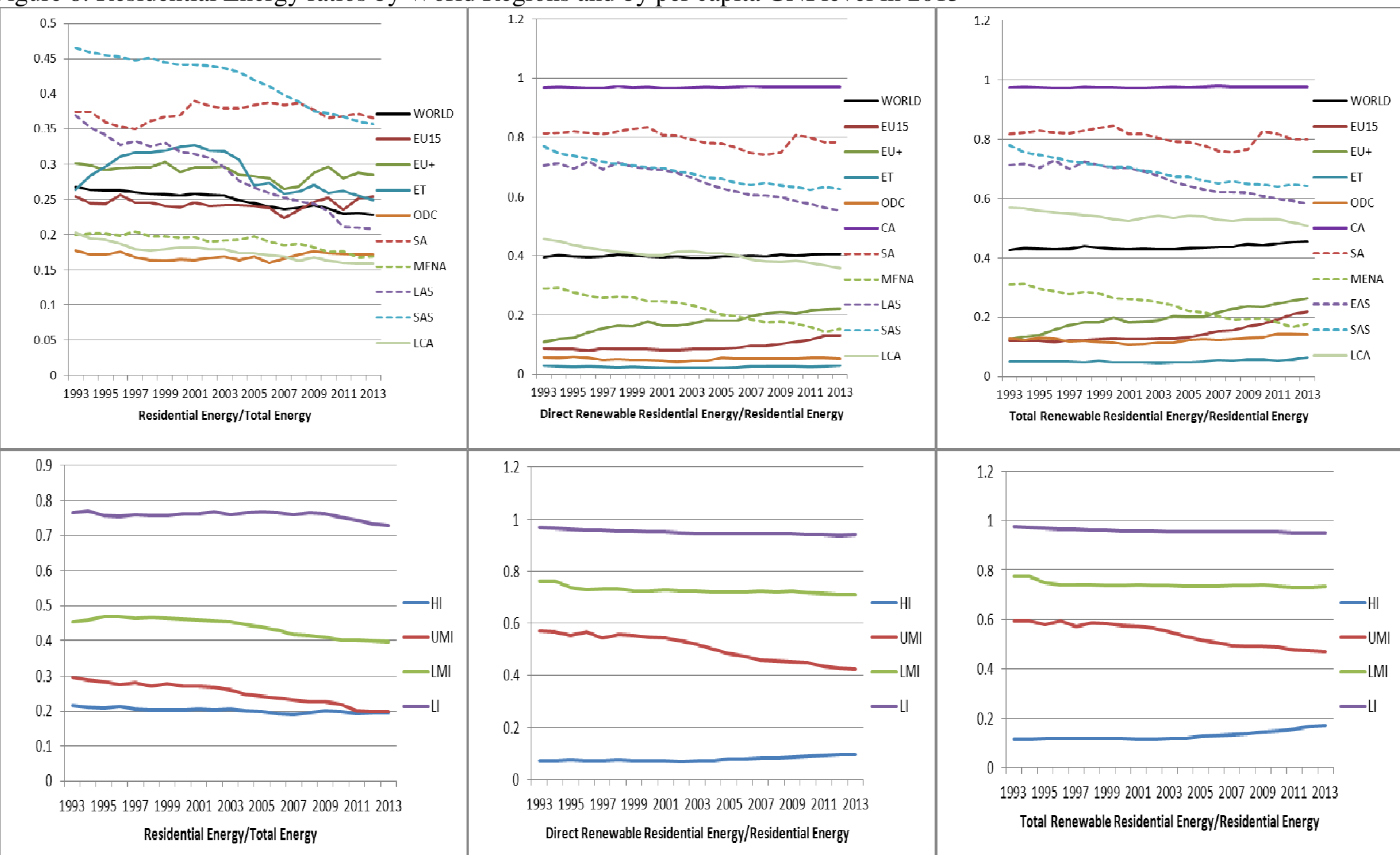

Source: Own production from IEA (2016). *CA region values do not appear in the first upper graphs as its values are around $80 \%$ and therefore much higher than in other regions. 